\title{
Faktor Penentu Profitabilitas Untuk Industri Tambang (Studi Pada 3 Negara : Indonesia, Kanada Dan Amerika Serikat Untuk Periode 2015 - 2016)
}

\author{
Magdalena ${ }^{1)}$ \\ yueling798@ymail.com \\ Temy Setiawan ${ }^{2)}$ \\ tsetiawan@bundamulia.ac.id \\ Universitas Bunda Mulia
}

\begin{abstract}
s
Profitability as one of the factors that can attract investors in making investment decisions should certainly be a concern of the company. Therefore, it is important for companies to improve or maintain profitability. The purpose of this study to provide empirical evidence of Corporate Social Responsibility (CSR), Leverage and Total Asset Turn Over affecting profitability.
\end{abstract}

This study population is a company engaged in the mining industry in the period 2015-2016 at United States, Indonesia and Canada. The data used are secondary data from the Annual Report and Sustainability Report of the company. The data test instruments use is SmartPLS 3.0.

These results of this study indicate that CSR, leverage, and Total Asset Turnover don't have an impact on profitability in the United States. While testing the data in Indonesia, said that a Total Asset Turnover positive effect on profitability and Corporate Social Responsibility (CSR) in Canada negative effect on profitability.

The research that related of CSR, leverage and Total Asset Turn Over are many found for the mining industry or other industry. But the novelty of this research is conducting test for the three highest mine producing countries in the world in the same observation period.

Keywords : Corporate Social Responsibility, Leverage, Total Asset Turnover, Profitability, Mining Industry, Canada, USA, Indonesia

\begin{abstract}
Abstrak
Profitabilitas sebagai salah satu faktor yang mampu menarik para investor dalam mengambil keputusan investasi tentu harus menjadi perhatian perusahaan. Oleh karena itu, penting bagi perusahaan dalam meningkatkan atau mempertahankan profitabilitas. Tujuan penelitian ini untuk memberikan pembuktian empiris Corporate Social Responsibility (CSR), leverage dan Total Asset Turn Over memengaruhi profitabilitas.

Populasi penelitian ini adalah perusahaan yang bergerak dalam industri pertambangan periode 2015-2016 di negara Amerika Serikat, Indonesia dan Kanada. Jenis data yang digunakan adalah data sekunder berupa Annual Report dan Sustainability Report perusahaan. Alat uji data yang digunakan adalah Smart PLS 3.0.

Hasil penelitian ini menunjukan bahwa CSR, leverage, dan Total Asset Turnover idak memiliki pengaruh terhadap profitabilitas di Amerika Serikat. Sedangkan pengujian data di Indonesia memberikan hasil bahwa Total Asset Turnover berpengaruh positif terhadap
\end{abstract}


profitabilitas dan Corporate Social Responsibility (CSR) di Kanada berpengaruh negatif terhadap profitabilitas.

Penelitian terkait CSR, leverage dan Total Asset Turn Over sudah banyak ditemukan baik untuk industri tambang ataupun industri lainnya. Namun kebaruan pada penelitian ini, melakukan pengujian untuk 3 negara penghasil tambang emas tertinggi di dunia pada periode pengamatan yang sama.

\section{Kata Kunci : Corporate Social Responsibility, Leverage, Total Asset Turnover, Profitabilitas, Industri Tambang, Kanada, Amerika, Indonesia}

\section{Pendahuluan}

Secara global pada tahun 2015 merupakan tahun penuh tantangan bagi sektor pertambangan. Terjadi penurunan harga komoditas sebesar $25 \%$, sehingga hal ini mendorong perusahaan pertambangan untuk mengoptimalkan kinerja. Dalam mengembangkan prasarana industri tentu akan membutuhkan investasi yang besar dan salah satu faktor dalam menarik para investor adalah meningkatkan kinerja keuangan perusahaan (Rizal, Kamaliya dan Agusti, 2017). Menurut Rahma dan Iramani (2015), kinerja keuangan perusahaan merupakan hal yang terpenting dikarenakan dalam kinerja keuangan akan mencerminkan bagaimana suatu perusahaan menjalankan kegiatan operasionalnya. Kinerja keuangan yang positif akan meningkatkan kepercayaan pemangku kepentingan yang pada akhirnya meningkatkan investasi dari penyandang dana (Aprianti \& Budiasih, 2016).

Salah satu indikator yang menjelaskan adanya peningkatan profitabilitas adalah Return On Asset (ROA). ROA merupakan rasio yang membandingkan laba sebelum pajak terhadap total aset perusahaan. Kinerja keuangan dalam suatu perusahaan akan semakin baik apabila perusahaan tersebut dapat menjaga nilai ROA karena dengan semakin besarnya ROA, maka tingkat pengembalian (return) yang diharapkan oleh perusahaan akan semakin besar dan hasilnya dapat dinikmati oleh pemegang saham (Dewi dan Wisadha, 2015; Iskandar dan Suardana, 2016). Oleh karena itu, profitabilitas, yang salah satunya dapat diukur dengan ROA merupakan hal penting yang perlu diperhatikan perusahaan.

Namun perusahaan tidak boleh hanya memperhatikan aspek profitabilitas sebagai keberhasilan kinerja. Aspek sosial dan lingkungan pun menjadi perhatian penting. Keberhasilan pada aspek lingkungan dan sosial akan mempengaruhi profitabilitas perusahaan (Saputra dan Setiawan, 2018). Dalam mencapai kinerja sosial dan lingkungannya, perusahaan perlu memperhatikan tanggung jawab sosial perusahaan terhadap eksternalitas (masyarakat, lingkungan, konsumen, pekerja). Apabila terjadi kegagalan dalam tanggung jawab sosial, maka berdampak pada profitabilitas yang menurun.

Seperti pada peristiwa yang terjadi di Indonesia yang diinformasikan pada tahun 2018, bahwa warga Gunung Karasik di Kalimantan Tengah, sungai Mansiwui dan sungai Garunggung yang merupakaan sumber air para warga rusak akibat aktivitas penambangan yang dibiarkan begitu saja tanpa adanya reklamasi yang layak (www.kompas.com). Kerusakan yang disebabkan oleh aktivitas penambangan cukup menimbulkan kerugian serta keresahan, seperti yang diungkapkan oleh Bhatnagar (2015) bahwa aktivitas penambangan dapat merusak lahan mata pencaharian warga lokal contohnya adalah pertanian. Penutupan tambang yang tidak layak juga dapat mewariskan kerusakan lingkungan. Terdapat mentalitas ketergantungan yang disebabkan oleh perusahaan yang menawarkan pekerjaan sebagai balasan atas kerusakan lingkungan dan sosial, kemudian hal tersebut akan menyebabkan banyaknya pengangguran usai aktivitas penambangan berakhir. Tidak hanya perusahaan 
pertambangan di Indonesia yang menyebabkan kerusakan lingkungan hidup dan sosial. Dalam laporan Harvard yang dirilis pada Oktober 2016 (www.environment.co.za) menyatakan bahwa, lapisan batubara yang membara, tumpukan penyimpanan batubara ataupun timbunan limbah batubara merupakan masalah lingkungan yang signifikan yang terjadi dibanyak negara termasuk China, Rusia, Amerika Serikat, Indonesia, Australia dan Afrika Selatan. Kebakaran batubara bawah tanah dapat terbakar selama berabad-abad dan mengisi atmosfer dengan asap yang mengandung karbon monoksida, karbon dioksida, metana, sulfur dioksida, nitrous oxides dan rumah kaca serta racun lainnya.

Dari pernyataan tersebut, dapat dilihat bahwa aktivitas pertambangan akan memberikan dampak yang buruk secara signifikan terhadap lingkungan dan juga hal tersebut dapat mengganggu kesehatan para pekerja serta warga lokal yang bertempat tinggal dekat dengan daerah pertambangan. Oleh karena itu keterlibatan perusahaan dalam aktivitas tanggung jawab sosial dan lingkungan sangat penting (Sun, 2015; Sriharan dan Vinasithamby, 2015; Siregar dan Kartikasari, 2017; Radyati, 2013). Penelitian ini akan menjadi penting untuk melihat apakah tanggung jawab sosial dan lingkungan perusahaan (Corporate Social Responsibility) akan memengaruhi profitabilitas untuk perusahaan yang ada di dalam industri tambang.

Dari kejadian nyata terkait aktivitas pertambangan yang tentu akan merusak lingkungan hidup dan sosial, perusahaan sangat diwajibkan untuk melakukan kegiatan pertanggungjawaban. Wujud pertanggungjawaban yang seharusnya dilakukan perusahaan yang sudah mulai bayak diterapkan adalah dengan melakukan kegiatan Corporate Social Responsibility (CSR) atau yang biasa dikenal degan tanggung jawab sosial. CSR sendiri memiliki tujuan untuk keberlangsungan bisnis perusahaan dengan menciptakan lingkungan yang sehat, masyarakat yang sejahtera dan ekonomi yang kuat (Radyati, 2013). Namun terdapat persepsi yang salah mengenai CSR, dikarenakan CSR pada hakikatnya merupakan investasi perusahaan dan bukan biaya yang habis pakai. Investasi yang dimaksudkan adalah mengenai citra perusahaan yang dapat membedakan perusahaannya dengan perusahaan kompetitor. Kesalahan persepsi terkait CSR akan dapat mengarahkan tindakan yang salah dan mengakibatkan kerugian pada pihak konsumen karena perusahaan akan membebankan biaya salah persepsi tersebut ke dalam biaya produksi yang akan menaikan harga produk maupun jasa yang dihasilkan.

Dalam konteks global, istilah CSR mulai digunakan sejak tahun 1970an dan semakin populer terutama setelah kehadiran buku Cannibals With Forks: The Triple Bottom Line in 21st Century Business (1998), karya John Elkington dimana ia mengemas CSR kedalam tiga fokus yang biasa disebut dengan 3P yang berasalkan singkatan dari profit, planet dan people. Kegiatan CSR dilakukan dengan tujuan untuk memberikan manfaat kepada shareholders serta stakeholders lainnya untuk meningkatkan kehidupan mereka menjadi lebih baik. Perusahaan perlu mengkomunikasikan terlebih dahulu mengenai kebutuhan apa yang dibutuhkan para stakeholders dan bukan menuruti apa yang ingin perusahaan lakukan. Perusahaan memiliki tanggung jawab sosial untuk beroperasi sesuai dengan etika yang berlaku yaitu bertanggung jawab terhadap sosial dan lingkungan. Manfaat dalam melaksanakan kebijakan CSR tidak hanya akan dirasakan oleh stakeholders maupun shareholders, namun juga akan dirasakan oleh perusahaan. Kegiatan CSR yang dilakukan perusahaan akan membangun kerjasama antara stakeholders dan perusahaan. Perusahaan dapat memfasilitasi para stakeholder dalam menyusun program-program yang dibutuhkan agar dapat beradaptasi dengan lingkungan. Hal tersebut dapat mempererat hubungan antara stakeholders dengan perusahaan agar terciptanya pembangunan yang berkelanjutan (sustainability development). 
Menurut Radyati (2013); Setiawan dan Augustine (2016), perusahaan yang telah menerapkan CSR pada perusahaannya akan mengungkapkan program CSR mereka kedalam laporan keberlanjutan atau laporan CSR. Laporan keberlanjutan perusahaan tentu dibuat sesuai dengan pedoman pelaporan kegiatan tanggung jawab sosial yang sudah sesuai yaitu Global Reporting Initiative (GRI) standard. Oleh karena itu, pada penelitian ini, pengukuran CSR perusahaan diukur dengan pengungkapannya.

Penelitian ini mengangkat 3 negara yang cukup berhasil dalam sektor tambang. Kanada, Amerika Serikat dan Indonesia merupakan top gold producing countries 2017 dari sekian banyak negara dalam berita yang dirilis pada tahun 2018 (www.focuseconomics.com). Tidak hanya terkenal sebagai top negara produsen emas di dunia, Kanada dan Amerika Serikat juga menyandang predikat sebagai top negara penghasil minyak di www.economy.okezone.com.

Sebuah perusahaan tentu akan membutuhkan modal dalam membiayai aktivitas operasional dan kegiatan lainnya yang berkaitan erat dengan keberlangsungan hidup perusahaan. Pada umumnya, pembiayaan untuk kegiatan operasional perusahaan berasal dari utang walau tidak sepenuhnya berasal dari utang. Pada industri pertambangan tentu akan melakukan kegiatan-kegiatan pendukung terlebih dahulu sebelum dilakukannya kegiatan penambangan. Contohnya adalah seperti melakukan eksplorasi lokasi penambangan, membutuhkan tenaga ahli serta aset tetap dengan tekonologi yang memadai dalam kegiatan penambangan. Hal tersebut tentu akan membutuhkan biaya yang cukup besar sebelum perusahaan dapat menghasilkan laba. Salah satu cara perusahaan dapat memperoleh biaya tersebut adalah melalui utang.

Penggunaan utang dalam pembiayaan kegiatan perusahaan tidak hanya memberikan dampak yang baik bagi perusahaan. Jika proporsi utang tidak diperhatikan oleh perusahaan, hal tersebut akan menyebabkan turunnya profitabilitas karena penggunaan utang menimbulkan beban bunga (Putra dan Badjra, 2015). Seorang investor tertarik pada perusahaan yang salah satunya memberikan pengembalian yang tinggi, sehingga ia akan menginvestasikan modalnya. Ketersediaan dana dari modal investor akan membuat perusahaan lebih mudah untuk menggunakan peluang investasi dalam menghasilkan laba.

Total Asset Turnover juga merupakan salah satu variabel yang dapat mempengaruhi profitabilitas (ROA). Menurut Kasmir (2015), Total Asset Turnover merupakan rasio yang digunakan untuk mengukur perputaran seluruh aktiva yang di miliki perusahaan. Hal yang ingin disampaikan dari Total Asset Turnover adalah bagaimana perusahaan dalam mengelola aktivanya secara optimal untuk menghasilkan penjualan yang tinggi. Industri pertambangan tentu membutuhkan aset dengan tekonologi yang memadai dalam kegiatan penambangan. Aset yang digunakan perusahaan dapat diperoleh dari pembelian aset maupun sewa. Biaya yang dikeluarkan perusahaan untuk memperoleh aset yang cukup besar menuntut perusahaan untuk dapat menggunakan aset tersebut semaksimal mungkin agar dapat menghasilkan laba yang diharapkan melalui penjualan. Jika penggunaan aset tersebut sudah dilakukan secara maksimal oleh perusahaan tentu dapat menjadi keunggulan dimata investor. Susilawati, Feriyanti, dan Nurlaelasari (2017) menyatakan bahwa semakin besar rasio Total Asset Turnover semakin baik karena hal ini menandakan aset perusahaan dapat lebih cepat berputar dan menghasilkan laba. Dalam penelitian Budiang, Pangeamanan, dan Gerungai (2017), Total Asset Turnover memiliki pengaruh positif terhadap profitabilitas. Namun dalam penelitian yang dilakukan oleh Susilawati, Feriyanto, dan Nurlaelasari (2017) menyatakan bahwa Total Asset Turnover secara parsial berpengaruh negatif signifikan terhadap profitabilitas.

Penelitian ini mengacu pada penelitian sebelumnya yang dilakukan oleh Sun (2012) yang meneliti pengaruh CSR terhadap kinerja keuangan perusahaan yang diproksikan pada 
Return on Asset. Hingga saat ini, penelitian yang mengangkat pengaruh CSR, Leverage dan Total Asset Turnover terhadap profitabilitas sudah cukup banyak dilakukan, namun yang menjadi pembeda penelitian ini dengan penelitian sebelumnya adalah pada penelitian ini mengangkat 3 negara yang cukup berhasil dalam sektor tambang. Kanada, Amerika Serikat dan Indonesia merupakan top gold producing countries 2017 dari sekian banyak negara dalam berita yang dirilis pada tahun 2018 (www.focus-economics.com). Tidak hanya terkenal sebagai top negara produsen emas di dunia, Kanada dan Amerika Serikat juga menyandang predikat sebagai top negara penghasil minyak di www.economy.okezone.com.

\section{Kerangka Teori dan Pengembangan Hipotesis \\ Teori Legitimasi (Legitimacy Theory)}

Teori legitimasi merupakan teori yang menjelaskan sebuah kondisi apakah perusahaan telah beroperasi sesuai dengan norma-norma etika yang berlaku dimasyarakat tanpa melewati batasan-batasan yang ada. Teori legitimasi merupakan sebuah sistem pengelolaan perusahaan yang berorientasi pada keberpihakan terhadap masyarakat. Oleh karena itu, perusahaan harus dapat beroperasi sesuai dengan harapan dari masyarakat. Teori legitimasi menganjurkan perusahaan untuk dapat meyakinkan bahwa aktivitas dan kinerja perusahaan serta produk atau jasa yang dihasilkan dapat diterima oleh masyarakat (Aprianti dan Budiasih, 2016; Dewi dan Suaryana, 2015). Menurut Rahmah \& Iramani (2015), legitimasi dari masyarakat merupakan faktor strategis bagi perusahaan dalam rangka mengembangkan perusahaan kedepan. Oleh sebab itu perusahaan perlu menjaga legitimasi stakeholder serta mendudukannya dalam rangka kebijakan dan pengambilan keputusan sehingga dapat mendukung pencapaian tujuan perusahaan, yaitu stabilitas usaha dan jaminan going concern. Keterkaitan teori ini dengan penelitian, untuk menjelaskan bagaimana CSR perusahaan sangat penting diperhatikan agar perusahaan bisa terus menjaga eksistensinya di tengah masyarakat dan beroperasi untuk menghasilkan laba.

\section{Teori Stakeholder (Stakeholder Theory)}

Teori Stakeholder merupakan salah satu teori utama yang banyak digunakan untuk mendasari penelitian tentang CSR. Salah satu pendukung teori ini adalah Freeman (1984) dan Donaldson dan Preston (1995) yang berpendapat bahwa teori stakeholder memperluas tanggungjawab organisasi kepada seluruh pemangku kepentingan yang tidak hanya berfokus kepada investor atau pemilik.

Keterkaitan teori stakeholder di dalam pembahasan penelitian ini adalah terdapat banyak pihak yang mempengaruhi atau yang terkena dampak dari kegiatan operasional perusahaan harus diperhatikan secara penuh oleh perusahaan. Perusahaan tidak dapat mengabaikan pihak stakeholder, namun perusahaan harus menjadikan pihak stakeholder sebagai salah satu pertimbangan dalam pengambilan keputusan. Hal ini dapat menjadi peluang bagi perusahaan untuk mendapatkan informasi terkait para stakeholders. Dengan menjadikan para stakeholders sebagai salah satu pertimbangan dalam pengambilan keputusan tentu akan menciptakan hubungan yang baik antara perusahaan dengan stakeholders dan para stakeholders akan bersikap kooperatif terhadap perusahaan sehingga perusahaan dapat berproduktivitas secara optimal untuk memperoleh laba. 


\section{Teori Sinyal (Signalling Theory)}

Teori sinyal adalah teori yang berhubungan dengan berhasil atau tidaknya manajemen dalam memberikan sinyal-sinyal dalam penyampaian informasi kepada pemilik. Teori sinyal juga dapat dikatakan sebagai teori yang memberikan suatu sinyal dimana pihak pengirim atau pemilik informasi berusaha memberikan suatu informasi yang relevan yang dapat dimanfaatkan oleh pihak penerima informasi (Maulana dan Yuyetta, 2014; Wijaya dan Sumiati, 2017). Pada penelitian ini CSR maupun rasio keuangan lainnya seperti leverage dan Total Asset Turn Over akan memberikan signal bagi profitabilitas perusahaan.

\section{Profitabilitas}

Profitabilitas merupakan rasio yang bertujuan untuk mengetahui kemampuan perusahaan dalam menghasilkan laba selama periode tertentu dan juga memberikan gambaran tentang tingkat efektifitas manajemen dalam melaksanakan kegiatan operasinya (Wardayani dan Wahyuni, 2016; Putra dan Badjra, 2015). Salah satu pengukuran kinerja keuangan perusahaan adalah dengan rasio profitabilitas dalam segi Return On Assets. Return On Asset (ROA) digunakan untuk mengukur profitabilitas karena memiliki kelebihan-kelebihan dibandingkan dengan analisis lain yaitu: dapat digunakan untuk mengukur efisiensi tindakan yang dilakukan oleh divisi, sifatnya yang menyeluruh berarti perusahaan telah menjalankan sistem akuntansinya dengan baik, dapat mengukur efisiensi penggunaan modal, produksi, dan bagian penjualan (Darmawan, Isynuwardhana dan Mahardika, 2018; Iskandar dan Suardana, 2016).

\section{Corporate Social Responsibility}

Corporate social responsibility dirancang untuk meningkatkan pencapaian kinerja sosial dan lingkungan disamping dari kinerja ekonomi yang memenuhi ekspektasi sebagian besar dari pemangku kepentingan (Rutlegde, Karim, Aleksanyan, dan Wu, 2015; Malau, Tugiman, dan Budiono, 2018; Hakim, 2016; Aryawan, Rahyuda dan Ekawati, 2017; Pattisahusiwa dan Diyanti, 2017; Lindawati dan Puspita, 2015). Tujuannya tidak lain untuk menjaga keberlangsungan usaha jangka panjang di dalam menghasilkan laba.

Di Indonesia, dasar hukum yang mengatur mengenai CSR yaitu UU No 40 Tahun 2007; UU No 25 Tahun 2007; UU No 32 Tahun 2009; UU No. 22 Tahun 2001. Melalui UU tersebut, negara diharapkan dapat berperan dalam meningkatkan kesadaran perusahaan untuk memperhatikan aspek sosial dan lingkungan untuk menghindari terjadinya legitimacy gap yang semakin melebar.

Atas aktifitas CSR, perlu dilakukan pengungkapan sebagai bagian dari pertanggungjawaban perusahaan. Pengungkapan dapat dilakukan dalam laporan tahunan maupun laporan keberlanjutan, Dengan demikian, peran laporan keberlanjutan akan semakin meningkat di masa yang akan datang (Kumar dan Pande, 2017).

\section{Leverage}

Leverage merupakan suatu rasio yang menunjukan sejauh mana perusahaan bergantung pada pembiayaan dalam bentuk utang. menjelaskan leverage timbul dari aktivitas penggunaan dana perusahaan yang berasal dari pihak ketiga dalam bentuk utang. Leverage perusahaan dihitung dengan menggunakan rasio perbandingan total utang dengan modal sendiri atau yang dikenal dengan debt to equity ratio (DER). DER merupakan proksi untuk mengevaluasi tingkat dari leverage perusahaan yang menunjukan hubungan yang sesuai dengan utang dan ekuitas perusahaan.

DER yang lebih rendah mengisyaratkan bahwa total utang lebih rendah dibandingkan dengan total ekuitas. Perusahaan yang memiliki tingkat leverage yang tinggi memiliki arti bahwa perusahaan sangat bergantung pada pinjaman luar untuk membiayai asetnya, 
sedangkan jika perusahaan memiliki tingkat leverage yang lebih rendah, maka perusahaan lebih banyak membiayai asetnya menggunakan modal sendiri (Sari dan Budiasih, 2014).

\section{Total Asset Turnover (TATO)}

Perusahaan memerlukan sejumlah aset usaha untuk menghasilkan volume penjualan yang ingin dicapai yang juga harus dioperasikan secara efisien (Susilawati, Feriyanto dan Nurlaelasari, 2017). Total Asset Turnover menurut Pramesti, Wijayanti dan Nurlaela (2016) adalah rasio yang digunakan untuk mewakili rasio aktivitas untuk mengukur keefektifan total aset yang dimiliki perusahaan dalam meghasilkan penjualan. Hal ini serupa dengan apa yang dinyatakan oleh Wikardi dan Wiyani (2017) terkait perputaran total aset. Total Asset Turnover merupakan rasio yang digunakan untuk menilai keefektifan total aset yang dimiliki perusahaan untuk mengukur jumlah penjualan yang akan dihasilkan dari setiap rupiah dana yang tertanam dalam total aset. Perputaran total aset yang rendah menandakan bahwa perusahaan memiliki kelebihan total aset, dimana total aset yang ada belum dimanfaatkan secara maksimal untuk menciptakan penjualan (Pramesti, Wijayanti dan Nurlaela, 2016).

\section{Pengaruh Corporate Social Responsibility (CSR) terhadap profitabilitas}

Menurut Parengkuan (2017), Corporate Social Responsibility dapat memberikan dampak positif bagi perusahaan, dimana dengan mempublikasikan aktivitas CSR, perusahaan dapat meningkatkan kepercayaan masyarakat terhadap produk perusahaan, sehingga reputasi perusahaan juga meningkat dimata masyarakat yang akan mempengaruhi kinerja keuangan perusahaan. Begitu juga menurut Prasetyo dan Meiranto (2017) pengungkapan CSR yang dilakukan perusahaan memiliki pengaruh positif terhadap ROA. Penelitian mengenai Corporate Social Responsibility dan profitabilitas perusahaan telah banyak dilakukan sebelumnya, baik yang memiliki hasil pengaruh positif maupun negatif. Hasil penelitian Mantaputri \& Widodo (2016) menjelaskan bahwa CSR tidak berpengaruh terhadap ROA. Namun pada penelitian yang dilakukan oleh Luthan, Rizki, \& Edmawati (2017) menunjukan bahwa pengungkapan CSR memiliki pengaruh terhadap kinerja keuangan yang diproksikan dengan ROA.

\section{H1 : Corporate Social Responsibility memiliki pengaruh terhadap Profitabilitas.}

\section{Pengaruh Leverage terhadap profitabilitas}

Perusahaan membutuhkan biaya untuk menjalankan aktivitas operasional perusahaannya, dimana salah satu sumber pembiayaan perusahaan adalah melalui utang. Debt to equity ratio (DER) adalah rasio yang dipergunakan untuk mengukur modal sendiri dari perusahaan yang dibiayai oleh utang. Semakin besar DER akan menunjukkan bahwa struktur pendanaan lebih banyak memanfaatkan utang dibandingkan dengan ekuitas sehingga perusahaan sewaktu-waktu harus siap untuk menunaikan kewajibannya dan hal ini akan berdampak terhadap laba perusahaan (Narayana, 2013). Pada penelitian Khan dan Khokhar (2015), leverage memiliki pengaruh signifikan terhadap profitabilitas perusahaan. Kemudian pada penelitian Putra \& Badjra (2015) dan Dewi dan Wisadha (2015) juga mendapati hasil yang serupa, yakni leverage berpengaruh positif terhadap profitabilitas. Namun pada penelitian yang dilakukan oleh Olang (2017) menunjukan hasil bahwa leverage tidak berpengaruh terhadap Profitabilitas.

\section{$\mathrm{H}_{2}$ : Leverage memiliki pengaruh yang signifikan terhadap Profitabilitas.}




\section{Pengaruh Total Asset Turn Over (TATO) terhadap profitabilitas}

Total Asset Turnover merupakan salah satu variabel yang harus diperhatikan dalam mengelola perusahaan. Perusahaan akan memerlukan aset untuk menghasilkan volum penjualan yang ingin dicapai sehingga aset yang dimiliki perusahaan tentu harus dioperasikan secara efisien. Total Asset Turnover yang tinggi dapat diartikan sebagai kemampuan manajemen dalam mengelola aktiva, baik aktiva lancar maupun aktiva tetap (Supardi, Suratno, \& Suyanto, 2016). Aset yang digunakan secara optimal dan efisien dapat meningkatkan pendapatan serta dapat menurunkan biaya tetap yang berasal dari aset tetap yang dimiliki perusahaan sehingga dapat memicu peningkatan laba (Wikardi \& Wiyani, 2017). Hal ini mengindikasikan bahwa jika Total Asset Turnover semakin tinggi, maka semakin tinggi tingkat profitabilitas perusahaan. Hal ini dapat mencerminkan bahwa perusahaan telah memanfaatkan aset yang ada dalam aktivitas operasionalnya secara efisien yang kemudian memicu peningkatan profitabilitas perusahaan. Hal ini sejalan dengan penelitian terdahulu dengan hasil bahwa Total Asset Turnover secara parsial berpengaruh positif terhadap profitabilias (Pramesti, Wijayanti dan Nurlaela, 2016). Dalam penelitian terdahulu yang dilakukan oleh Supardi, Suratno, \& Suyanto (2016) juga menghasilkan hal yang serupa yaitu Total Asset Turnover secara parsial berpengaruh terhadap ROA. Sedangkan pada penelitian Widodo (2018) menunjukan bahwa Total Asset Turnover tidak berpengaruh terhadap $R O A$.

\section{H3 : Total Asset Turnover memiliki pengaruh yang signifikan terhadap} Profitabilitas.

Gambar 1

Model Penelitian

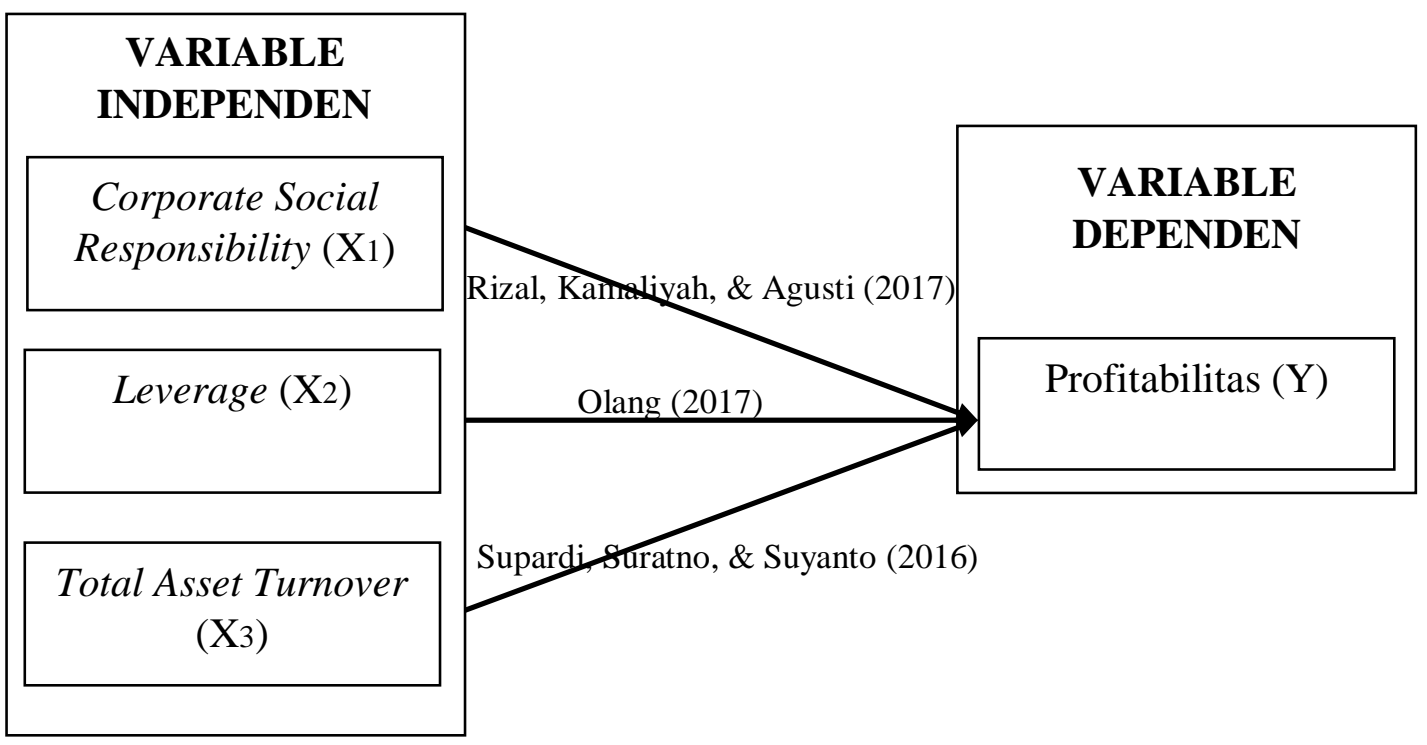

Sumber: Hasil Olahan Penulis

Metode Penelitian 
Penelitian ini merupakan penelitian kuantitatif yang bersifat asosiatif. Subjek penelitian adalah perusahaan mining, oil and gas yang terdaftar di bursa efek masing - masing negara (Indonesia, Amerika dan Kanada). Objek penelitian adalah laporan tahunan dan laporan keberlanjutan yang dipublikasikan perusahaan. Jenis data adalah data sekunder dengan teknik pengumpulan data yaitu studi literatur. Periode penelitian yaitu 2015 dan 2016. Pengolahan data menggunakan Smart PLS 3.0.

Penggunaan PLS untuk melihat indikator reflektif mana yang menjelaskan variabel CSR. Dari model yang digambarkan pada outer model, akan tampak aspek sosial, ekonomi atau lingkungan yang lebih mendominasi CSR pada masing- masing negara. Selain itu, penggunaan PLS karena jumlah data yang terbatas dan tidak memerlukan pengujian normalitas dan asumsi klasik.

Sampel perusahaan sebanyak 18 perusahaan di Amerika; 12 perusahaan di Indonesia dan 16 perusahaan di Kanada. Profitabilitas di proksikan dengan ROA; Leverage dengan Debt Equity Ratio dan CSR dengan indek pengungkapan di dalam laporan keberlanjutan (menggunakan indikator GRI 4). Untuk menentukan skor dalam index pengungkapan menggunakan konten analisis (Setiawan dan Augustine, 2016).

\section{Hasil dan Pembahasan}

\section{Gambar 2}

\section{Model Pengukuran (Outer Model) Amerika Serikat}

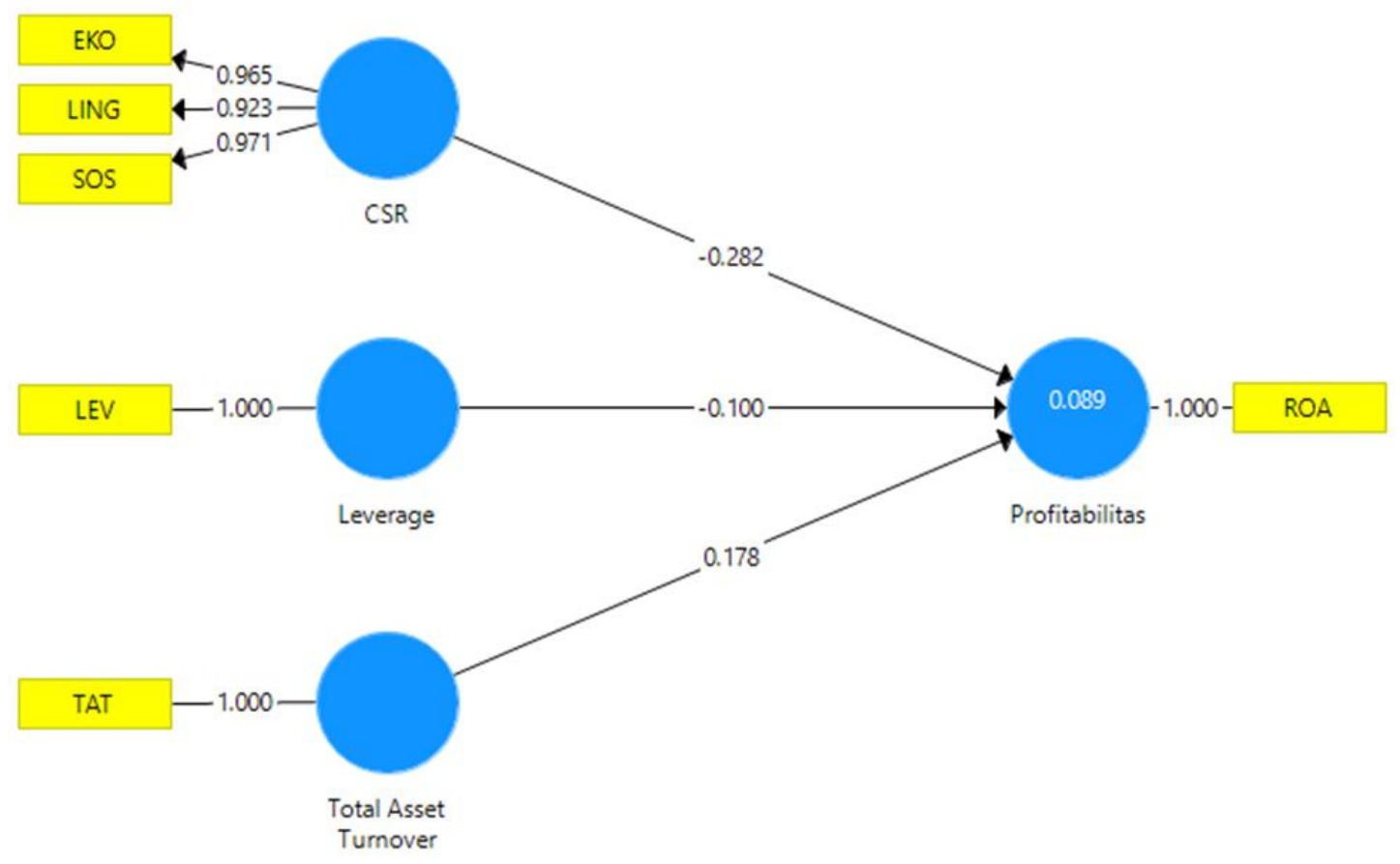

Sumber: Hasil pengolahan data dengan SmarPLS 3.0 


\section{Gambar 3}

Model Pengukuran (Outer Model) Indonesia

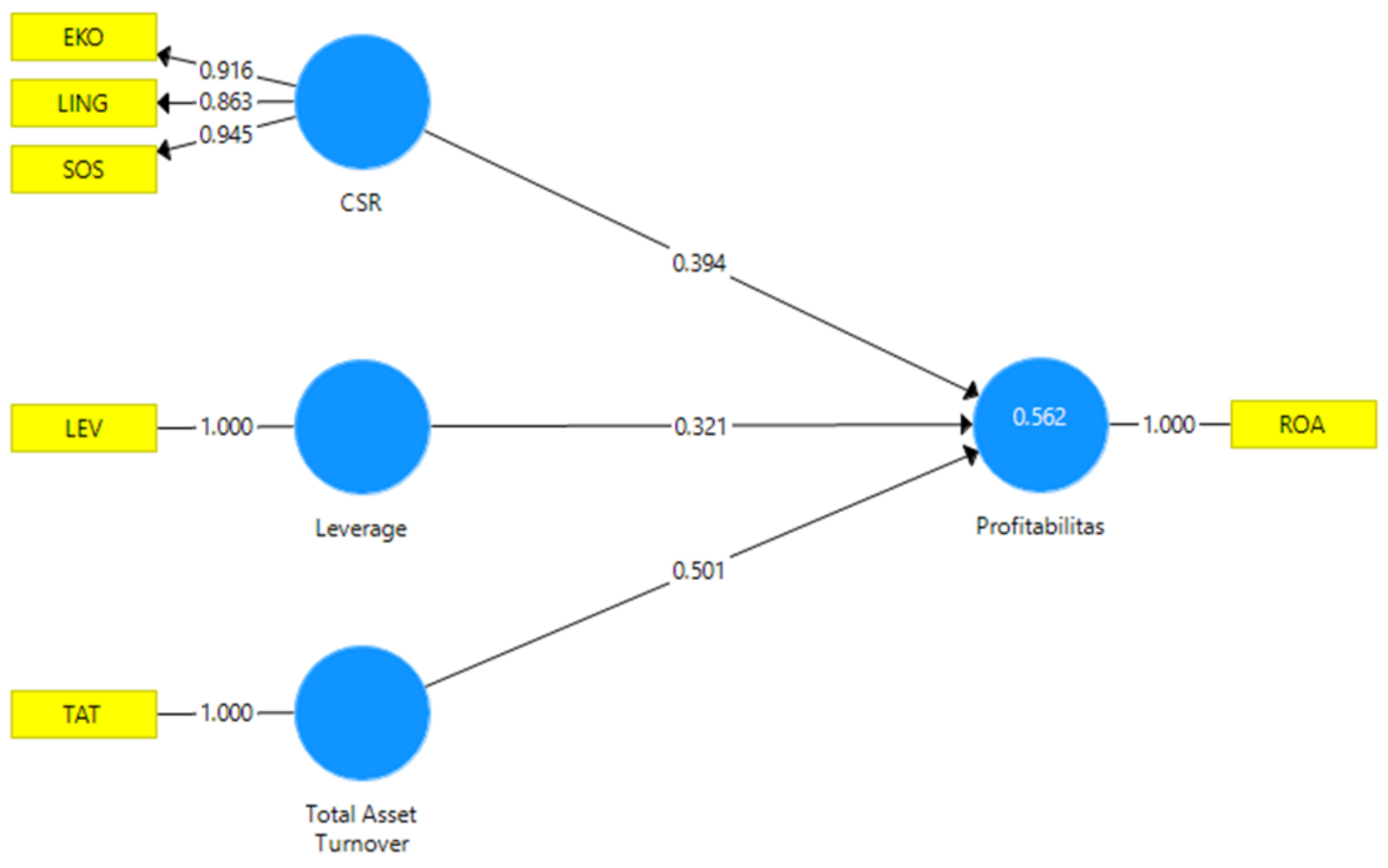

Sumber: Hasil pengolahan data dengan SmarPLS 3.0

Gambar 4

Model Pengukuran (Outer Model) Kanada

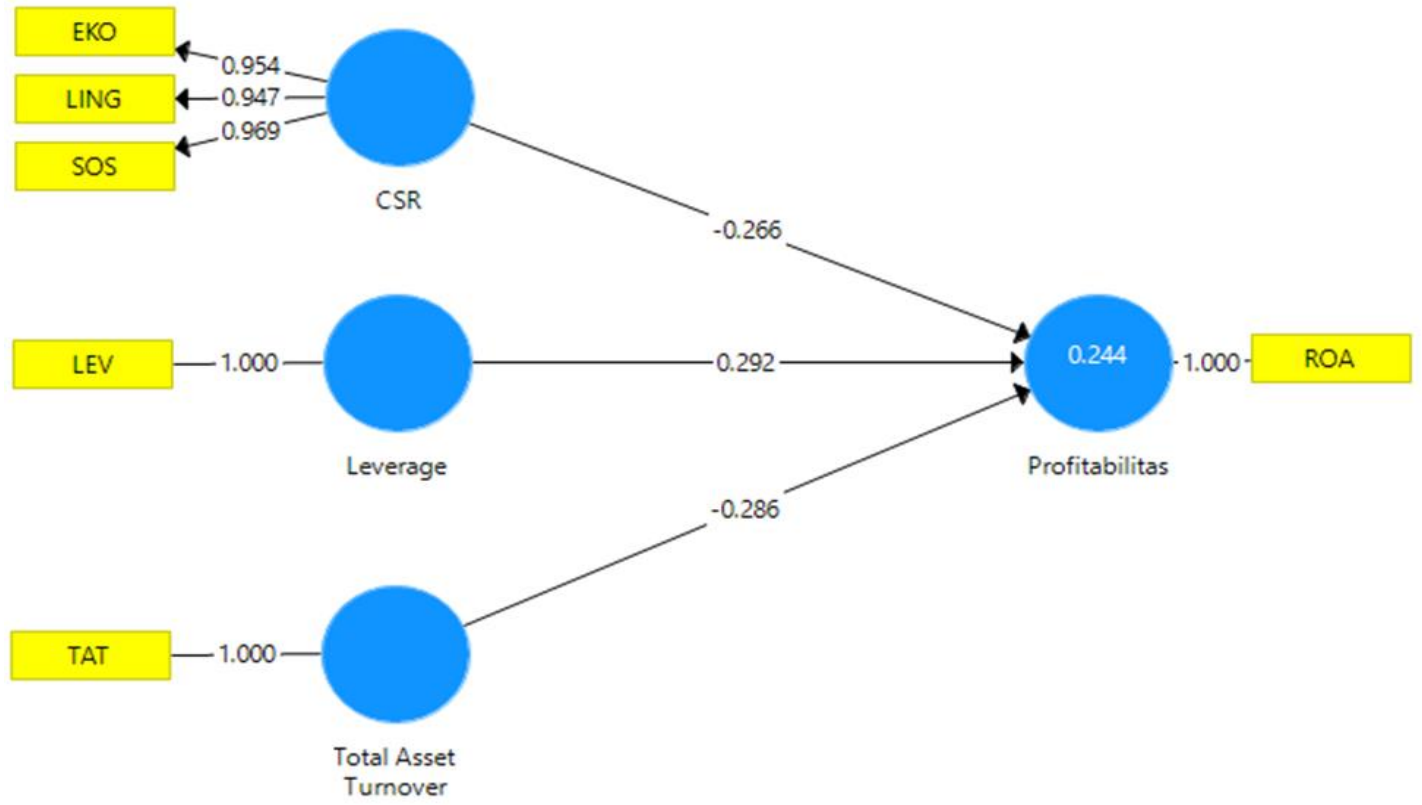

Sumber: Hasil pengolahan data dengan SmarPLS 3.0 


\section{Tabel 1}

Path Coefficients

\begin{tabular}{|c|c|c|c|c|c|c|c|}
\hline \multirow[t]{2}{*}{ 目 Mean, } & \multicolumn{2}{|c|}{ D Confidence Intervals } & \multicolumn{3}{|c|}{ Confidence Intervals Bias C... } & Samples & Copy to Clipboa \\
\hline & Original Sampl... & Sam & ple Mean (... & Standard Devia... & & Statistics $(\mid 0 \ldots$ & P Values \\
\hline CSR $\rightarrow$ Profitabilitas & -0.282 & & -0.280 & 0.161 & & 1.752 & 0.080 \\
\hline Leverage $->$ Profitabilitas & -0.100 & & -0.124 & 0.263 & & 0.381 & 0.703 \\
\hline Total Asset Turnover -> Profitabilit & 0.178 & & 0.189 & 0.128 & & 1.395 & 0.164 \\
\hline
\end{tabular}

\section{Hasil Uji Hipotesis Amerika Serikat}

Sumber: Hasil pengolahan data dengan SmartPLS 3.0

Tabel 2

\section{Hasil Uji Hipotesis Indonesia}

\section{Path Coefficients}

\begin{tabular}{|c|c|c|c|c|c|c|c|}
\hline \multirow[t]{2}{*}{ 囷 } & \multicolumn{2}{|c|}{ Confidence Intervals } & \multicolumn{3}{|c|}{ Confidence Intervals Bias C... } & Samples & \multirow{2}{*}{$\begin{array}{c}\text { Copy to Clipboar } \\
\text { P Values }\end{array}$} \\
\hline & Original Sampl... & Sam & ple Mean (... & Standard Devia... & & Statistics $(\mid 0 \ldots$ & \\
\hline CSR $\rightarrow$ Profitabilitas & 0.394 & & 0.201 & 0.326 & & 1.207 & 0.228 \\
\hline Leverage $\rightarrow>$ Profitabilitas & 0.321 & & 0.207 & 0.234 & & 1.371 & 0.171 \\
\hline Total Asset Turnover $\rightarrow>$ Profitabilitas & 0.501 & & 0.543 & 0.164 & & 3.052 & 0.002 \\
\hline
\end{tabular}

Sumber: Hasil pengolahan data dengan SmartPLS 3.0

Tabel 3

\section{Hasil Uji Hipotesis Kanada}

\section{Path Coefficients}

\begin{tabular}{|c|c|c|c|c|c|c|c|c|}
\hline \multirow[t]{2}{*}{ Mean, STDEV, T-Values, $\mathrm{P}$} & \multicolumn{2}{|c|}{ (1) Confidence Intervals } & \multicolumn{3}{|c|}{ Confidence Intervals Bias $C$... } & Samples & \multicolumn{2}{|c|}{ Copy to Clipboard: } \\
\hline & Original Sampl... & Sam & iple Mean (... & Standard Devia... & & Statistics (|0/STD & DEVl) & P Values \\
\hline CSR $\rightarrow>$ Profitabilitas & -0.266 & & -0.233 & 0.114 & & & 2.339 & 0.020 \\
\hline Leverage $->$ Profitabilitas & 0.292 & & 0.261 & 0.289 & & & 1.012 & 0.312 \\
\hline Total Asset Turnover $>>$ Profitabilitas & -0.286 & & -0.208 & 0.332 & & & 0.861 & 0.390 \\
\hline
\end{tabular}

Sumber: Hasil pengolahan data dengan SmartPLS 3.0

\section{Corporate Social Responsibility Terhadap Profitabilitas}

Dari hasil uji hipotesis di tabel 1 pada negara Amerika Serikat dan tabel 2 pada negara Indonesia, tampak pada tingkat signifikansi 95\%, CSR tidak berpengaruh terhadap 
profitabilitas. Namun lain hal tabel 3 menunjukan bahwa CSR berpengaruh pada profitabioitas untuk Kanada.

Hal yang menyebabkan CSR tidak berpengaruh signifikan terhadap profitabilitas di Amerika Serikat dan Indonesia adalah adanya niat perusahaan yang hanya ingin memenuhi ketentuan hukum dan menjalankan akitivitas operasional sesuai dengan norma yang berlaku (Saputra dan Setiawan, 2018; Tarigan dan Semuel, 2014; Verbeeten dan Moller, 2016; Raar, 2002; Prasetyo dan Meiranto, 2017; Lin dan Amin, 2016). Dengan demikian pengungkapan CSR hanya formalitas dan informasi yang disampaikan cenderung naratif dan positif. Hal ini tidak ditangkap pemangku kepentingan dan mempengaruhi kinerja profitabilitas perusahaan.

Pada pengungkapan CSR di Kanada, pengungkapan yang tertinggi terdapat pada elemen ekonomi. Di Kanada pengungkapan CSR lebih fokus pada elemen ekonomi dimana hal ini juga diinformasikan dalam www.international.gc.ca bahwa Kanada banyak membantu perekonomian di negara tempat perusahaan pertambangan Kanada beroperasi yang mayoritas lokasinya berada di negara-negara berkembang. Biaya yang dikeluarkan perusahaanperusahaan di Kanada untuk melakukan dan melaporkan kegiatan CSR perusahaan yang besar akan menurunkan laba sebelum pajak perusahaan yang akan mempengaruhi Return on Asset perusahaan.

\section{Leverage Terhadap Profitabilitas}

Tabel 1, tabel 2 dan tabel 3 menjelaskan bahwa tidak terdapat pengaruh leverage terhadap profitabilitas. Hal ini disebabkan karena pada dasarnya pembiayaan melalui utang hanya akan menambah biaya berupa bunga yang harus dibayarkan perusahaan. Walaupun pembayaran bunga dapat dimanfaatkan untuk menghemat pajak, namun tetap saja pembiayaan utang akan menurunkan profitabilitas (Olang, 2017; Noor, Sinaga dan Maulana, 2015; Mustafa, Saeed dan Zafar, 2017).

\section{Total Asset Turnover (TATO) Terhadap Profitabilitas}

Tabel 1 dan tabel 3 menunjukan bahwa TATO tidak berpengaruh pada profitabilitas untuk perusahaan di Amerika dan Kanada, namun tabel 2 menjelaskan bahwa TATO berpengaruh terhadap profitabilitas untuk perusahaan di Indonesia.

Kanada dengan nilai rata-rata Total Asset Turnover yang tidak berbeda jauh dengan Amerika menunjukan bahwa perusahaan-perusahaan di Kanada dan Amerika belum memaksimalkan penggunaan aset yang dimiliki perusahaan untuk menghasilkan penjualan. Berdasarkan data pada sampel penelitian ini menunjukan bahwa mayoritas perusahaan di Kanada laba (rugi) sebelum pajaknya tidak sejalan dengan peningkatan atau penurunan penjualan perusahaan. Sehingga dapat disimpulkan bahwa Total Asset Turnover di Kanada tidak berpengaruh signifikan terhadap profitabilitas karena naik turunnya penjualan perusahaan tidak hanya dapat dilihat pada penggunaan aset, namun juga terdapat aktivitas eksplorasi dan usaha untuk mendapatkan suatu proyek yang tentu juga mengeluarkan biaya yang akan menjadi pengurang dari total penjualan untuk mendapatkan laba atau rugi sebelum pajak perusahaan. Hasil dari penelitian ini bertolak belakang dengan penelitian yang dilakukan oleh Widodo (2018) namun sejalan dengan penelitian yang di lakukan oleh Sunjoko \& Arilyn (2016).

Indonesia yang memiliki rata-rata Total Asset Turnover tertinggi dari ketga negara yang dibandingkan. Hal ini mencerminkan bahwa perusahaan di Indonesia dapat memanfaatkan aset-aset yang dimiliki perusahaan secara maksimal. Mayoritas perusahaan di Indonesia yang dijadikan sampel penelitian memperlihatkan bahwa laba (rugi) sebelum pajak searah dengan meningkatnya atau menurunnya penjualan perusahaan. Hal ini dapat mempengaruhi profitabilitas perusahaan karena perusahaan dapat memaksimalkan 
penggunaan aset perusahaannya sehingga penjualan perusahaan meningkat dan mempengaruhi tingkat ROA perusahaan. Hasil penelitian di Indonesia sejalan dengan penelitian yang dilakukan oleh Budiang, Pengemanan \& Gerungai (2017) namun tidak sejalan dengan penelitian yang dilakukan oleh Sunjoko \& Arilyn (2016).

\section{Simpulan dan Saran}

Dari penelitian di atas, tampak bahwa setiap negara walaupun dalam industri yang sama tidak memberikan hasil pengujian yang sama. Di Amerika tidak ada variabel independen yang diuji dan memberikan hasil berpengaruh terhadap profitabilitas. Sedangkan di Kanada CSR berpengaruh pada profitabilitas. Di Indonesia, leverage berpengaruh terhadap profitabilitas. Dengan adanya hasil penelitian ini akan memberikan gambaran bagi investor bahwa pengungkapan CSR di Kanada akan memberikan dampak pada kinerja perusahaan jangka pendek dalam memaksimalkan aset yang dimiliki. Bagi perusahaan di Kanada, penting sekali di dalam pengungkapan CSR. Untuk perusahaan di Indonesia, di dalam peningkatan profitabilitas perlu diperhatikan komposisi pendanaan yang diukur dengan debt to equity. Debt financing yang tinggi meningkatkan bunga dan berdampak pada profitabilitas karena meningkatkan beban yang ditandingkan.

Penelitian ini pun memberikan peluang penelitian ke depan bahwa lingkungan bisnis dan kebijakan makro akan memengaruhi hubungan CSR, leverage dan TATO terhadap profitabilitas. Maka kebijakan makro ataupun lingkungan bisnis dapat dijadikan pemoderasi. Penelitian ini pun akan membuka peluang penelitian lainnya untuk membandingkan Indonesia dengan negara lainnya yang memiliki ciri kesamaan dalam industri ataupun kondisi makro.

\section{DAFTAR REFERENSI}

Apriyanti, N. W., \& Budiasih, I. A. (2016). Profitabilitas dan Corporate Social Responsibility Pada Perusahaan High dan Low Profile. E-Jurnal Akuntansi Universitas Udayana, 977-1004.

Aryawan, M., Rahyuda, I. K., \& Ekawati, N. W. (2017). Pengaruh Faktor Corporate Social Responsibility (Aspek Sosial, Ekonomi dan Lingkungan) Terhadap Citra Perusahaan. E-Jurnal Manajemen Unud, Vol. 6, No. 2,, 604-633.

Bhatnagar, D. S. (2015). Corporate Social Responsibility of Mining Industries. International Journal of Law and Management Vol.57 No.5, 367-372.

Budiang, F. T., Pangemanan, S. S., \& Gerungai, N. Y. (2017). Pengaruh Perputaran Total Aset, Perputaran Piutang Dan Perputaran Persediaan Terhadap ROA Pada Perusahaan 
Sub Sektor Perdagangan Eceran Yang Terdaftar Di BEI. Jurnal EMBA Vol.5 No.2, 1956-1966.

Darmawan, A., Isynuwardhana, D., \& Mahardika, D. P. (2018). Pengaruh Good Corporate Governance Dan Corporate Social Responsibility Terhadap Kinerja Keuangan Perusahaan. e-Proceeding of Management : Vol.5, No.1, 595.

Dewi, N. M., \& Suaryana, I. A. (2015). Pengaruh Profitabilitas dan Kepemilikan Asing Pada Pengungkapan Corporate Social Responsibility. E-Jurnal Akuntansi Universitas Udayana 13.1, 84-98.

Dewi, N. T., \& Wisadha, I. G. (2015). Pengaruh Kualitas Aktiva Produktif, CAR, Leverage dan LDR Pada Profitabilitas Bank. E-Jurnal Akuntansi Universitas Udayana Vol.12 No.2, 295-312.

Hakim, D. A. (2016). Urgensi Penerapan Corporate Social Responsibility Sebagai Upaya Menjamin Hak-Hak Tenaga Kerja. Fiat Justisia Journal Volume 10 Issue 4, 587-814.

Iskandar, A. F., \& Suardana, K. A. (2016). Pengaruh Ukuran Perusahaan, Return On Asset, Dan Winner/ Loser Stock Terhadap Praktik Perataan Laba. E-Jurnal Akuntansi Universitas Udayana Vol.14 No.2, 805-834.

Kasmir. (2015). Analisis Laporan Keuangan. Edisi Pertama. Cetakan kedelapan. Jakarta: Rajawali Pers.

Khan, M. N., \& Khokhar, I. (2015). The Effect of Selected Financial Ratios on Profitability: An Empirical Analysis of Listed Firms of Cement Sector in Saudi Arabia. Quarterly Journal of Econometrics Research Vol.1 No.1, 1-12.

Kumar, R., \& Pande, N. (2017). Developing a GRI-G4 Based Persuasive Communication Framework for Sustainability Reporting (SR): Examining Top 10 Indian Banks. International Journal of Emerging Markets Vol.13 Issue.1, 136-161.

Lin, H. Y., \& Amin, N. (2016). The Relationship Between Corporate Social Performance and Financial Performance: Evidences From Indonesia and Taiwan. European Journal of Business and Social Sciences Vol.5 No.3, 50-62.

Lindawati, A. L., \& Puspita, M. E. (2015). Corporate Social Responsibility: Implikasi Stakeholder dan Legitimacy GAP Dalam Peningkatan Kinerja Perusahaan. Jurnal Akuntansi Multiparadigma (JAMAL), 1-174.

Luthan, E., Rizki, S. A., \& Edmawati, S. D. (2017). Pengaruh Pengungkapan Tanggung Jawan Sosial Perusahaan Terhadap Kinerja Keuangan. Jurnal Ekonomi dan Keuangan Vol 1 No.2, 204-219.

Malau, N. S., Tugiman, H., \& Budiono, E. (2018). Pengaruh Good Corporate Governance dan Corporate Social Responsibility Terhadap Kinerja Keuangan. e-Proceeding of Management : Vol.5 No.1, 583.

Mantaputri, N., \& Widodo, A. (2016). Pengaruh Pengungkapan Corporate Social Responsibility Terhadap Kinerja Keuangan Perusahaan Asuransi yang Terdaftar di BEI Tahun 2010-2014. e-Proceeding of Management : Vol.3, No.3, 3529. 
Maulana, F., \& Yuyetta, E. N. (2014). Pengaruh Karakteristik Perusahaan Terhadap Pengungkapan Corporate Social Responsibility (CSR). Diponegoro Journal of Accounting Vol.3 No.2, 1-14.

Mustafa, D., Saeed, A., \& Zafar, A. (2017). The Effect of Financial Leverage And Market Size on Stock Returns on Karachi Stock Exchange: Evidence From Selected Stocks in the Non-Financial Sector of Pakistan. The International Journal Of Business \& Management Vol.5 No.10, 246-252.

Narayana, I. P. (2013). Pengaruh Perputaran Kas, Loan to Deposito Ratio, Tingkat Permodalan dan Leverage Terhadap Profitabilitas Bank Perkreditan Rakyat (BPR)) Se-Kota Denpasar Periode 2009-2011. E-Jurnal Akuntansi Universitas Udayana Vol.3 No.2, 334-350.

Noor, T., Sinaga, B., \& Maulana, T. A. (2015). Testing on Pecking Order Theory and Analysis of Company's Characteristic Effects on Emitten's Capital Structure. Indonesian Journal of Business and Entrepreneurship Vol 1 No 2, 81-89.

Olang, M. (2017). Effect of Financial Leverage on Profitability of Firm Listed in the Nairobi Securities Exchange. International Journal of Science and Research Vol 6 Issue 7, 2319-7064.

Parengkuan, W. E. (2017). Pengaruh Corporate Social Responsibility Terhadap Kinerja Keuangan Perusahaan Manufaktur yang Terdaftar di Bursa Efek Indonesia Melalui Pojok Bursa FEB-UNSRAT. Jurnal EMBA Vol 5 No. 2, 564-571.

Pattisahusiwa, S., \& Diyanti, F. (2017). Pengungkapan Corporate Social Responsibility, Struktur Corporate Governance dan Nilai Perusahaan. Jurnal Ekonomi Modernisasi, 25-36.

Pramesti, D., Wijayanti, A., \& Nurlaela, S. (2016). Pengaruh Rasio Likuiditas, Leverage, Aktivitas dan Firm Size Terhadapt Profitabilitas Perusahaan Sub Sektor Otomotif dan Komponen Di Bursa Efek Indonesia. Seminar Nasional IENACO, 810-817.

Prasetyo, A., \& Meiranto, W. (2017). Pengaruh Corporate Social Responsibility Terhadap Kinerja Keuangan Perusahaan Manufaktur Yang Terdaftar Di BEI Tahun 2013-2015. Diponegoro Journal of Accounting Vol.6 No.3, 1-12.

Putra, A. W., \& Badjra, I. B. (2015). Pengaruh Leverage, Pertumbuhan Penjualan dan Ukuran Perusahaan Terhadap Profitabilitas. E-Journal Manajemen Unud Vol.4 No.7, 20522067.

Raar, J. (2002). Enviromental Initiatives: Towards Triple-Bottom Line Reporting. Corporate Communication: An International Journal Vol 7 No.3, 169-183.

Radyati, M. N. (2013). Sustainable Business dan Corporate Social Responsibility (CSR). Jakarta: Center for Entrepreneurship, Change and Third Sector Trisakti University.

Rahmah, P. A., \& Iramani, R. (2015). Pengaruh Corporate Social Responsibility Pada Kinerja Keuangan Perusahaan Pertambangan. Journal of Business and Banking Vol.5 No.2, 195-212. 
Rizal, Y., Kamaliyah, \& Agusti, R. (2017). Pengaruh Corporate Social Responsibility Terhadap Kinerja Keuangan, Dengan Leverage Dan Ukuran Perusahaan Sebagai Variabel Kontrol . Jurnal Akuntansi Vol.5 No.2, 145-158.

Rutlegde, R., Karim, K., Aleksanyan, M., \& Wu, C. (2015). An Examination of the Relationship Between Corporate Social Responsibility And Financial Performance: The Case of Chinese State Owner Enterprises. Advances in Environmental Accounting \& Management, Volume 5, , 1-22.

Saputra,W dan Setiawan, T. (2018). Pengaruh Corporate Social Responsibility Disclosure (CSRD), Nilai perusahaan dan Profitabilitas. Balance Vocation Accounting Journal. Vol 2, No 1.

Sari, N. V., \& Budiasih, I. A. (2014). Pengaruh Debt to Equity Rratio, Firm Size, Inventory Turnover dan Assets Turnover Pada Profitabilitas. E-Jurnal Akuntansi Universitas Udayana Vol.6 No.2, 261-273.

Setiawan, T dan Augustine, Y. (2016). Etika Lingkungan dan Kinerja Ekonomi Pada Ukuran Global Reporting Initiative G4. Jurnal Akuntansi Atma Jaya. Volume 10, No 1.

Siregar, C. A., \& Kartikasari, D. (2017). Hubungan Corporate Social Responsibility Terhadap Kinerja Keuangan Perusahaan . Jurnal Akuntansi, Ekonomi dan Manajemen Bisnis Vol. 5 No.1, 72-79.

Sritharan, \& Vinasithamby. (2015). Does Firm Size Influece on Firm's Profitability? Evidence from Listed Firms of Sri Lankan Hotels adn Travels Sector. Research Journal of Finance and Accounting Vol.6 No.6, 201-2017.

Sun, L. (2012). Further Evidence on the Association Between Corporate Social Responsibility and Financial Performance. International Journal of Law and Management Vol 54 No.6, 472-484.

Sun, M. S. (2015). Corporate Governance and Social Responsibility. International Journal of Law and Management Vol.57 No.1.

Sunjoko, M. I., \& Arilyn, E. J. (2016). Effect of Inventory Turnover, Total Asset Turnover, Fixed Asset Turnover, Current Ratio and Average Collection Period on Profitability. Jurnal Bisnis dan Akuntansi Vol 18 No.1 , 79-83.

Supardi, H., Suratno, H., \& Suyanto. (2016). Pengaruh Current Ratio, Debt To Asset Ratio. Total Asset Turnover Dan Inflasi Terhadap Return On Asset. Jurnal Ilmiah Akuntansi Fakultas Ekonomi Vol.2 No.2, 16-27.

Susilawati, Feriyanto, O., \& Nurlaelasari, D. (2017). Pengaruh Perputaran Persediaan dan Perputaran Total Aset Terhadap Profitabilitas pada PT Indofarma (Persero) Tbk. StarStudy \& Accounting Research Vol XIV No.1, 36-43.

Tarigan, J., \& Semuel, H. (2014). Pengungkapan Sustainability Report dan Kinerja Keuangan. Jurnal Akuntansi dan Keuangan, Vol. 16, No. 2, 88-101. 
Verbeeten, F., Gamerschlag, R., \& Moller, K. (2016). Are CSR disclosure relevant for investors? Empirical evidence from Germany. Management Decision, 25.

Wardayani, \& Wahyuni, D. S. (2016). Analisis Return on Asset, Current Ratio dan Debt Ratio dalam Menilai Kinerja Keuangan pada PT. Pelabukan Indonesia I (Persero) cabang Belawan. Jurnal Ilman, Vol. 4, No. 1, 59-73.

Widodo, A. (2018). Analisis Pengaruh Current Ratio (CR), Total Asset Turnover (TATO), Dan Debt To Asset Ratio (DAR) Terhadap Return On Asset (ROA), Serta Dampaknya Terhadap Nilai Perusahaan. Jurnal Ilmiah Manajemen Forkamma, 87112.

Wijaya, E., \& Sumiati, N. (2017). The Effect of The Financial Performance, Firm Size and The Disclosure of Corporate Social Responsibility of The Firm Value at Manufacturing Companies in 2013-2015 Periods in Indonesia Stock Exchange. BILANCIA Vol. 1 No. 3, 348-359.

Wikardi, L. D., \& Wiyani, N. T. (2017). Pengaruh Debt to Equity Ratio, Firm Size, Inventory Turnover, Asset Turnover dan Pertumbungan Penjualan Terhadap Profitabilitas. Journal Online Insan Akuntan Vol.2 No.2, 99-118. 